NUREG / CR-4402

Volume 2

ORNL/TM-9798/V2

OAK RIDGE

NATIONAL

LABORATORY

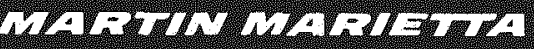

\title{
High-Temperature Gas-Cooled Reactor Safety Studies for the Division of Accident Evaluation Quarterly Progress Report, April 1-June 30, 1985
}

\author{
S. J. Ball \\ J. C. Cleveland \\ R. M. Harrington \\ J. H. Wilson
}

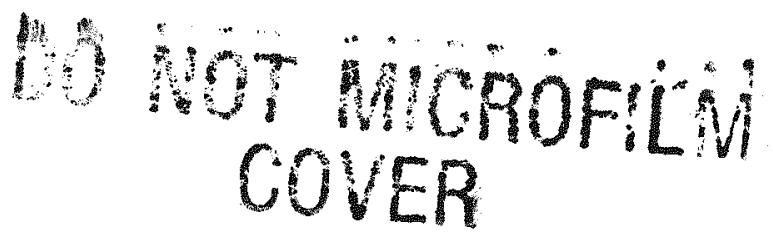

Prepared for the U.S. Nuclear Regulatory Commission Office of Nuclear Regulatory Research

Under Interagency Agreements DOE 40-551-75 and 40-552-75 


\section{NOTICE}

This report was prepared as an account of work sponsored by an agency of the United States Government. Noither the United States Government nor any agency thereof, of any of their employees, makes any warranty, expressed or implied, or assumes any legal liability or responsibility for any third party's use, or the results of such use, of any information, apparatus product or process disclosed in this report, or represents that its use by such third party would not infringe privately owned rights.

Available from

Superintendent of Documents

U.S. Govermment Printing Office

Post Ofice Box 37082

Washington, 0.C. 20013-7982

and

National Tochnical Intormation Service

Springfield, VA 22161 


\section{DISCLAIMER}

This report was prepared as an account of work sponsored by an agency of the United States Government. Neither the United States Government nor any agency Thereof, nor any of their employees, makes any warranty, express or implied, or assumes any legal liability or responsibility for the accuracy, completeness, or usefulness of any information, apparatus, product, or process disclosed, or represents that its use would not infringe privately owned rights. Reference herein to any specific commercial product, process, or service by trade name, trademark, manufacturer, or otherwise does not necessarily constitute or imply its endorsement, recommendation, or favoring by the United States Government or any agency thereof. The views and opinions of authors expressed herein do not necessarily state or reflect those of the United States Government or any agency thereof. 


\section{DISCLAIMER}

Portions of this document may be illegible in electronic image products. Images are produced from the best available original document. 
NUREG/CR-4402

Volume 2

ORNL/TM-9798/V2

This report was prepared as an account of work sponsored by an agency of the United States Government. Neither the United States Government nor any agency thereof, nor any of their employees, makes any warranty, express or implied, or assumes any legal liability or responsibility for the accuracy, completeness, or usefulness of any information, apparatus, product, or process disclosed, or represents that its use would not infringe privately owned rights. Reference herein to any specific commercial product, process, or service by trade name, trademark, manufacturer, or otherwise does not necessarily constitute or imply its endorsement, recommendation, or favoring by the United States Government or any agency thereof. The views and opinions of authors expressed herein do not necessarily state or reflect those of the United States Government or any agency thereof.
Dist. Category R8

\section{HIGH-TEMPERATURE GAS-COOLED REACTOR SAFETY STUDIES FOR \\ THE DIVISION OF ACCIDENT EVALUATION QUARTERLY \\ PROGRESS REPORT, APRIL 1-JUNE 30, 1985}

S. J. Ba11, Manager

J. C. Cleveland

R. M. Harrington

J. H. Wilson
NUREG/CR $--4402-\mathrm{VOI} \cdot 2$

TI86 005982

Manuscript Completed - January 21, 1986

Date Published - February 1986

NOTICE: This document contains information of a preliminary nature. It is subject to revision or correction and therefore does not represent a final report.

Prepared for the MASTER

U.S. Nuclear Regulatory Commission

Office of Nuclear Regulatory Research

Under Interagency Agreements DOE 40-551-75 and 40-552-75

NRC FIN No. B0122

Prepared by the

OAK RIDGE NATIONAL LABORATORY

Oak Ridge, Tennessee 37831

operated by

MARTIN MARIETTA ENERGY SYSTEMS, INC.

for the

U.S. DEPARTMENT OF ENERGY

under Contract No. DE-AC05-840R21400 


\section{$111 \mathrm{fr}$}

CONTENTS

Page

PRIOR HTGR SAEETY REPORTS $\ldots \ldots \ldots \ldots \ldots \ldots \ldots \ldots \ldots \ldots \ldots \ldots \ldots \ldots \ldots \ldots \ldots$

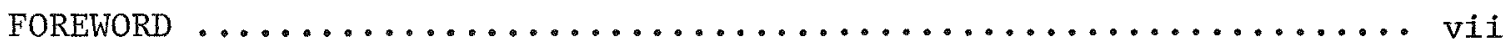

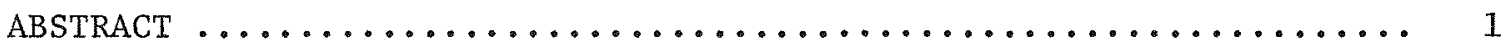

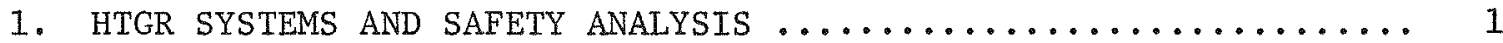

1.1 Investigations of Modular HTGR Dynamics ............. 1

1.2 Fission-Product Release from HTGRs ............... 4

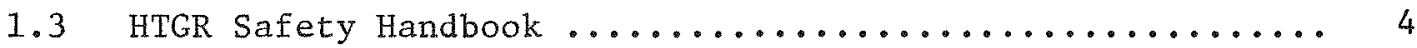

1.4 Review of FSV Reactor Technical Specifications on Limiting Maximum Core Temperatures ................ 5

1.5 Cooperative Programs with the Federal Republic of Germany .............................. 5

2. TRIPS MADE UNDER PROGRAM SPONSORSHTP $\ldots \ldots \ldots \ldots \ldots \ldots \ldots \ldots \ldots$

2.1 Mid-Year Program Review, NRC-Bethesda, Maryland,

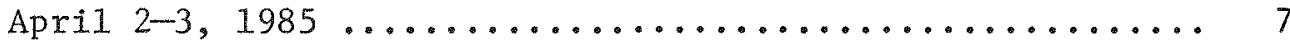

2.2 IAEA Specialists Meeting on Gas-Cooled Reactor Safety and Accident Analysis, Oak Ridge, Tennessee,

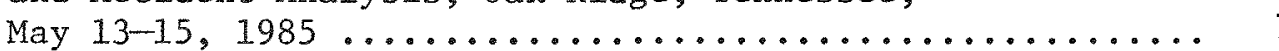

2.3 DOE/NRC Meeting on Licensing Plans for the Advanced HTGR Plant Design, Bethesda, Maryland, May 31, 1985 ..... 7

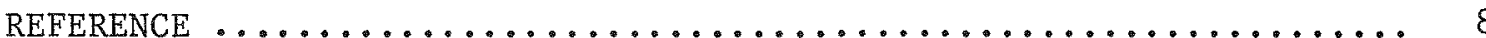



PRIOR HTGR SAFETY REPORTS

\section{Quarterly Progress Reports}

Ending date

September 30, 1974

December 31, 1974

March 31, 1975

June 30,1975

September 30, 1975

December 31, 1975

March 31, 1976

June 30, 1976

September 30, 1976

December 31, 1976

March 31, 1977

June 30,1977

September 30, 1977

December 31, 1977

March 31, 1978

June 30, 1978

September 30, 1978

December 31, 1978

March 31, 1979

June 30,1979

September 30, 1979

December 31, 1979

March 31, 1980

June 30,1980

September 30,1980

December 31, 1980

March 31, 1981

June 30, 1981

September 30, 1981

December 31, 1981

March 31, 1982

June 30, 1982

September 30, 1982

December 31, 1982

March 31, 1983

June 30,1983

September 30,1983

December 31, 1983

March 31, 1984

June 30,1984

September 30, 1984

December 31, 1984

March 31, 1985
Designation

ORNL/TM-4798

ORNL/TM-4805, Vol. IV

ORNL/TM-4914, Vo1. IV

ORNL/TM-5021, Vo1. IV

ORNL/TM-5128

ORNL/TM-5255

ORNL/NUREG/TM-13

ORNL/NUREG/TM-43

ORNL/NUREG/TM-66

ORNL/NUREG/TM-96

ORNL/NUREG/TM-115

ORNL/NUREG/TM-138

ORNL/NUREG/TM-164

ORNL/NUREG/TM-195

ORNL/NUREG/TM-221

ORNL/NUREG/TM-233

ORNL/NUREG/TM-293

ORNL/NUREG/TM-314

ORNL/NUREG/TM-336

ORNL/NUREG/TM-356

ORNL/NUREG/TM-366

ORNL/NUREG/TM-383

ORNL/NUREG/TM-397

ORNL/NUREG/TM-415

ORNL/NUREG/TM-429

ORNL/TM-7809

ORNL/TM-7889

ORNL/TM-8091

ORNL/TM-8128

ORNL/TM-8260

ORNL/TM-8443/V1

ORNL/TM-8443/V2

ORNL/TM-8443/V3

ORNL/TM-8443/V4

ORNL/TM-8921/VI

ORNL/TM-8921/V2

ORNL/TM-8921/V3

ORNL/TM-8921/V4

ORNL/TM-9267/V1

ORNL/TM-9267/V2

ORNL/TM-9267/V3

ORNL/TM-9267/V4

ORNL/TM-9798/V1 
vi

\section{Topical Reports}

S. J. Ba11, ORECA-I: A Digital Computer Code for Simulating the Dynamics of HTGR Cores for Emergency Cooling Analyses, ORNL/TM-5159 (Apri1 1976).

T. W. Ker1in, HTGR Steam Generator Modeling, ORNL/NUREG/TM-16 (Ju1y 1976).

R. A. Hedrick and J. C. Cleveland, BLAST: A Digital Computer Program for the Dynamic Simulation of the High Temperature Gas Cooled Reactor Reheater-Steam Generator Module, ORNL/NUREG/TM-38 (August 1976).

J. C. Cleveland, CORTAP: A Coupled Neutron Kineties-Heat Transfer Digital Computer Program for the Dynamic Simulation of the High Temperature Gas Cooled Reactor Core, ORNL/NUREG/TM-39 (January 1977).

J. C. Cleveland et al., ORTAP: A Nuclear Steam Supply System Simulation for the Dynamic Analysis of High Temperature Gas Cooled Reactor Transients, ORNL/NUREG/TM-78 (September 1977).

S. J. Ball et a1., Evaluation of the General Atomic Codes TAP and RECA for HTGR Accident Analyses, ORNL/NUREG/TM-178 (May 1978).

J. C. Conklin, ORTURB: A Digital Computer Code to Determine the Dynamic Response of the Fort St. Vrain Reactor Steam Turbines, ORNL/NUREG/TM-399 (March 1981).

S. J. Ball et a1., Summary of ORNL Work on NRC-Sponsored HTGR Safety Research, July 1974-September 1980, ORNL/TM-8073 (March 1982). 
FOREWORD

High-temperature gas-cooled reactor safety studies at Oak Ridge National Laboratory are sponsored by the Division of Accident Evaluation (formerly the Division of Reactor Safety Research), which is part of the Office of Nuclear Regulatory Research of the Nuclear Regulatory Commission.

This report covers work performed from April 1 to June 30, 1985. Previous quarterly reports and topical reports published to date are listed on pages $\mathrm{v}$ and $\mathrm{vi}$. Copies of the reports are available from the Technical Information Center, U.S. Department of Energy, Oak Ridge, TN 37831. 


\section{HIGH-TEMPERATURE GAS-COOLED REACTOR SAFETY STUDIES FOR THE DIVISION OF ACCIDENT EVALUATION QUARTERLY \\ PROGRESS REPORT, APRIL 1-JUNE 30, 1985}

\section{S. J. Bal1, Manager}

J. C. Cleveland R. M. Harrington

$$
\text { J. H. Wilson }
$$

\section{ABSTRACT}

Modeling, code development, and analyses of the modular High-Temperature Gas-Cooled Reactor (HTGR) continued with work on the side-by-side design. Fission-product release and transport experiments were completed. Sections of an HTGR safety handbook were written.

\section{HTGR SYSTEMS AND SAFETY ANALYSIS}

Work for the Division of Accident Evaluation (formerly Reactor Safety Research) under the High-Temperature Gas-Cooled Reactor (HTGR) Systems and Safety Analysis Program began in July 1974, and progress is reported quarterly. Work during this quarter included continuation of model and code development for the modular HTGRs. Fission-product (FP) release and transport experiments and technical assistance work on a Fort St. Vrain (FSV) technical specification (tech spec) review were continued. Work was initiated on sections of an HTGR Safety Handbook.

\subsection{Investigations of Modular HTGR Dynamics}

\section{R. M. Harrington S. J. Ball}

A paper entitled "Simulation of Thermal Response of the 250 MWT Modular HTGR During Hypothetical Uncontrolled Heatup Accidents" was prepared and presented on May 14, 1985, at the International Atomic Energy Agency (IAEA) Specialists Meeting on Gas-Cooled Reactor Safety and Accident Analysis. The conference was held at Oak Ridge National Laboratory (ORNL) May 13-15, 1985. The abstract for this paper is reproduced below:

One of the central design features of the 250 MWT modular HTGR is the ability to withstand uncontrolled heatup accidents without severe consequences. This paper describes calculational studies, conducted at Oak Ridge National Laboratory under the auspices of the U. S. Nuclear Regulatory Commission's HTGR Research Program, to test this important design feature. A multi-node thermal-hydraulic model of the 250 MNT modular HTGR reactor core was developed and implemented in the IBM CSMP (Continuous System Modeling Program) simulation language. 
The code is capable of predicting the peak fuel, reflector, and reactor vessel temperatures reached following permanent loss of forced primary coolant circulation accidents with or without concomitant loss of steam generator cooling water flow or accidental depressurization of the helium primary coolant. Survey calculations show that the loss of forced circulation accident with loss of steam generator cooling water and with accidental depressurization is the most severe heatup accident. The peak hot-spot fuel temperature is in the neighborhood of $1600^{\circ} \mathrm{C}$. Fuel failure and fission product releases for such accidents would be minor. Sensitivity studies show that code input assumptions for thermal properties such as the side reflector conductivity have a significant effect on the peak temperature.

A computer model of the reactor vessel cavity concrete wall and its surrounding earth was developed. This model was used to simulate the extremely unlikely and very slowlydeveloping heatup accident that would take place if the worstcase loss of forced primary coolant circulation accident were further compounded by the loss of cooling water to the reactor vessel cavity liner cooling system. The simulation results show that the ability of the earth surrounding the cavity to act as a satisfactory long-term heat sink is very sensitive to the assumed rate of decay heat generation and on the effective thermal conductivity of the earth. Soll properties at some sites may not be suitable.

As part of the continuing study of the dynamics of modular HTGR core heatup accidents, several runs were made to learn more about the significance of the heat loss from the exterior of the reactor vessel. The dynamic simulator code described in the recent quarterly reports was used to perform the necessary calculations; input applicable to the vertical in-line concept was retained.

The accident chosen for study is the depressurized loss-of-forced convection (LOFC) with the concomitant failure of the steam generator feedwater system. Heat flow from the exterior of the reactor vessel to the surrounding reactor cavity, and its liner cooling system, would play an important part in the eventual recovery from this accident. The calculations, described below, were performed to evaluate the effect of this heat loss on average and maximum fuel temperatures during the first day or two following accident initiation.

For the first calculation, a LOFC with loss of feedwater was assumed, and the heat removal from the exterior of the reactor vessel was reduced by assuming failure of the liner cooling system (LCS) and by assigning an artificially high value of thermal resistance between the cavity liner and its concrete wall. In this case the predicted maximum hot node fuel temperature of $1567^{\circ} \mathrm{C}$, occurring after $24 \mathrm{~h}$, is only $17^{\circ} \mathrm{C}$ higher than the peak for the analogous LOFC with the LCS running (and with no increase in liner-to-concrete thermal resistance).

To obtain a result with a more clear-cut difference, it was decided that the next calculation should be an LOFC with loss of feedwater in which the heat loss from the exterior of the reactor vessel is held at 
zero. This cannot be done by any physical means but is easily accomplished by modifying the programming of the simulation model to set the heat loss from the reactor vessel to zero throughout the whole accident. In this case the predicted maximum hot node fuel temperature is only $30^{\circ} \mathrm{C}$ higher than for the analogous case with the LCS running, but the average fuel temperature peak is $60^{\circ} \mathrm{C}$ higher. As expected, there is a dramatic difference in reactor vessel temperatures for the two cases. The maximum vessel temperature is $532^{\circ} \mathrm{C}$ after $36 \mathrm{~h}$ for the no-heat-1oss case, $247^{\circ} \mathrm{C}$ higher than the case with nominal vessel heat loss and LCS operation.

A more complete comparison between these two cases is presented in Fig. 1 for the first $36 \mathrm{~h}$ following accident initiation. From this figure we see that the difference between hot node temperatures is truly small but that the behavior of average fuel temperature is significantly different. The average temperature for the no-heat-loss case, although decreasing slowly at the $36-\mathrm{h}$ point, would begin to increase again some time after $36 \mathrm{~h}$ and would continue to do so thereafter. The average fuel temperature for the nominal heat loss case is under control and decreasing rapidly after $36 \mathrm{~h}$.

The conclusion from these cases is that, during the first several days after accident initiation, cavity cooling is not very important to the peak hot node fuel temperature, somewhat important to average fuel temperature, and very important to reactor vessel temperature. This

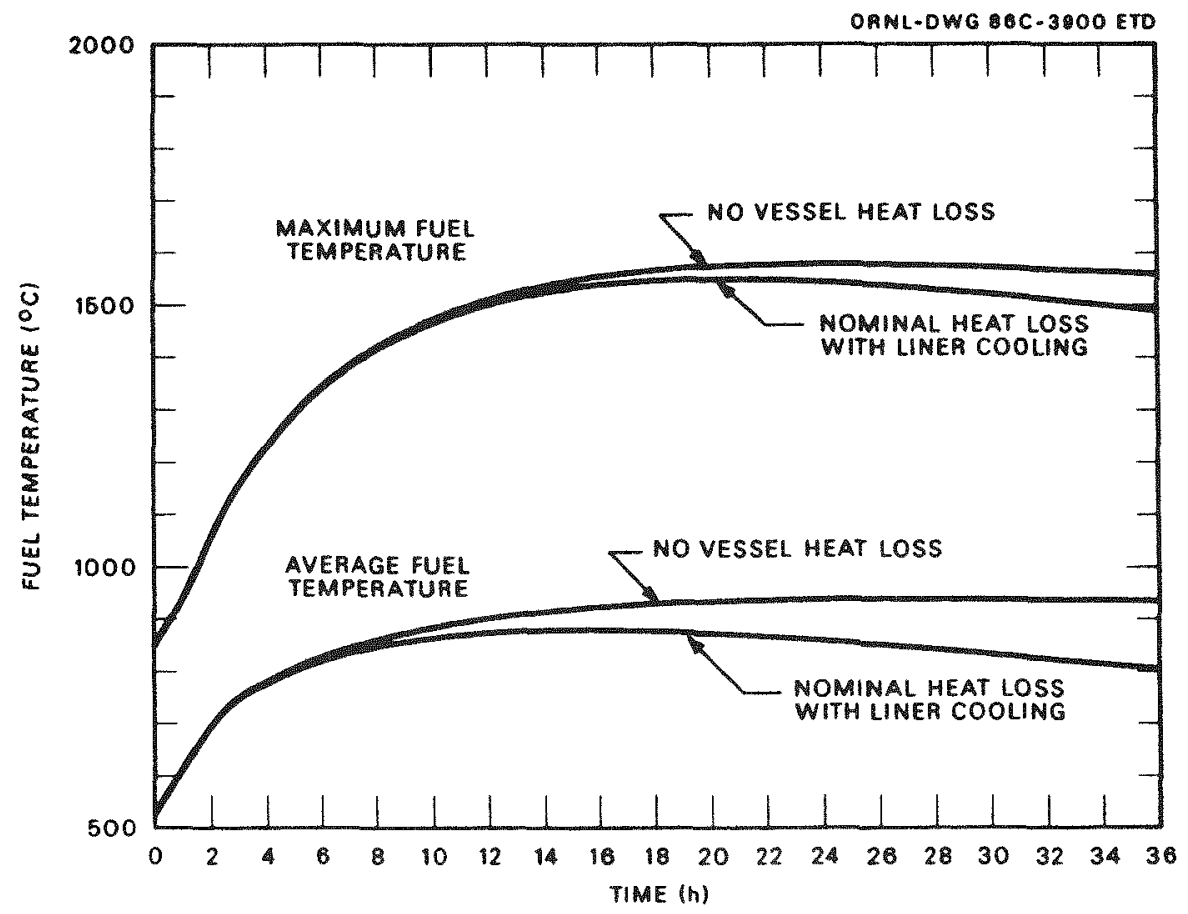

Fig. 1. Effect of reactor vesse1 heat loss on fuel temperatures for the loss of forced-convection accident. 
result is reasonable because the peak fuel temperature occurs near the center of the core, which is separated from the outside of the reactor vessel by several meters thickness of fuel pebbles and graphite reflector blocks.

\title{
1.2 Fission-Product Release from HTGRs
}

\author{
J. H. Wilson C. M. Simmons
}

The objective of this task is to generate experimental data required for the analysis of FP release in HTGR severe accidents. Initial efforts involved the determination of FP vapor pressures and diffusion rates through graphite. These data are required for calculation of the rate of transport of FPs from failed fuel particles through graphite to the coolant. In the next phase, the interaction of FPs with prestressed concrete reactor vessel (PCRV) materials of construction will be studied. The experimental data will be used for the prediction of FP retention in the PCRV.

Several diffusion experiments using both the graphite tube and the open-end zirconia tube were performed after a reanalysis of experimental. data showed the need for these additional tests. The results were incorporated into the report on the FP transport studies. As discussed in the last quarterly report, a draft report was written that covered the work for the past 1.5 years on FP vapor pressures and diffusion coefficients in graphite. The main conclusion of this report was that the transport of the FPs that were studied (AI, Ce, La, $\mathrm{Pd}, \mathrm{Pr}, \mathrm{Rh}, \mathrm{Ru}$, and $Y$ ) was described by a gas phase diffusion model. The draft report was prepared for submission and review.

Work on the study of FP interaction with materials of construction was initiated. The objective of the experimental design is to generate data that will be applicable to both HTGRs and PWRs. A preliminary design of an experimental apparatus was made. Plans are to use the high-temperature graphite resistance furnace to perform tests on the interaction of FPs with steel. This should provide information useful for the final equipment design.

\subsection{HTGR Safety Handbook}

\begin{tabular}{ll} 
S. J. Ball & J. C. Mailen \\
J. C. Cleveland & D. L. Moses \\
J. C. Conklin & J. P. Sanders \\
R. M. Harrington & R. P. Wichner \\
\multicolumn{4}{l}{ J. H. Wilson }
\end{tabular}

ORNL was assigned to write major sections of the HTGR Safety Handbook (other contributors are Brookhaven National Laboratory and Los Alamos National Laboratory). This handbook is to be an up-to-date, complete, and reliable data base as well as a general reference source for HTGR safety technology. It is designed to be applicable to FSV as well as to the advanced (modular) HTGR designs. Drafts or finished versions of major parts of the following sections were written and 
reviewed during the reporting period: Section 2 (NSSS Descriptions), Section 3 (Component and Subsystem Descriptions), Section 4 (Design Basis Accidents), Section 8 (Fission Product Release and Transport), Section 9 (Core Physics), Section 10 (Material and Equipment Aging), and Section 11 (Safety Issues). More work on sections 2, 8, and 9 is planned for the near term.

\subsection{Review of FSV Reactor Technical Specifications on Limiting Maximum Core Temperatures}

$$
\text { S. J. BaII }
$$

The ORNL review of the FSV tech spec limiting conditions for operation (ICO) 4.1 .9 addresses limiting maximum core temperatures during low-power (0 to $15 \%$ ) operation. It is sponsored primarily by a subcontract with the Nuclear Regulatory Commission (NRC) Region IV and is part of a large tech spec upgrade program.

A series of low-power, low-flow "benchmark" scenarios, set up in a cooperative effort with GA Technologies (GAT), were run and analyzed using the modified version of the ORECA code, " which calculates intraregion flow redistributions. The main conclusions were that with equal refueling region orifice settings, the minimum flows needed to prevent stagnation, under the most conservative sets of high region peaking factors (RPF) conditions, are $4 \%$ at $1 \%$ power and $5 \%$ at $5 \%$ power. In the latter case, however, out-of-limits core exit and fuel temperatures occur at flows as high as $13 \%$. Cases were also run for a worst-case minimum RPF (0.4) and maximum column power tilt factor (1.507). The ORECA code predictions, when the refueling region orifices are adjusted for nearly-equal region outlet temperatures, show that at 1 east $4 \%$ flow is needed (with $1 \%$ power) to avoid intraregion flow stagnation. However, with an arbitrary minimum orifice setting of $10 \%$, flow stagnation does not occur in the critical regions until the flow is reduced to $\sim 2 \%$. This indicates a possible desirable operating strategy. Benchmark comparisons showed that the differences between the ORNL (ORECA code) results and GAT's calculations were relatively small for the $1 \%$ power case. However, GAT's analysis of the $5 \%$ power case indicated that considerably more total core flow would be required to prevent flow stagnation in the critical region than ORNL's analysis had shown. Work on explaining this difference is continuing.

These and other aspects of the problem, such as heatup times and corrective measures, were discussed in a summary letter report to NRC.

\subsection{Cooperative Programs with the Federa1 Republic of Germany}

J. C. Cleveland

A meeting was held on May 17 at ORNL with $W$. Rehm and E. Teuchert of KFA-Jülich. ORNL personnel included S. J. Ball, R. M. Harrington, D. L. Moses, and J. C. Cleveland. The main focus of the meeting was to identify potential areas of cooperation between ORNL and KFA. Areas 
identified included code development and validation, accident analysis, development of theoretical models for pebble bed heat transfer under accident conditions, and risk analysis. Technical discussions included KFA and ORNL dynamic analysis capabilities for HTRs and a presentation by KFA of results of their analysis of THTR safety. 
2. TRIPS MADE UNDER PROGRAM SPONSORSHIP

$$
\text { 2.1 } \frac{\text { Mid-Year Program Review, }}{\frac{\text { NRC-Bethesda, Maryland, }}{\text { Apri1 2-3,1985 }}}
$$
S. J. Ball
R. M. Harrington
J. C. Cleveland
J. H. Wilson

ORNL presentations at the meeting summarized accomplishments in the areas of FP diffusion experiments, code development and verification, and accident analyses. A major purpose of the meeting was to advise the Office of Nuclear Reactor Regulation Advanced Reactors Group of the tools and capabilites available to handle the upcoming licensing work on the Department of Energy's modular HTGR plant design. The meeting was held jointly with the BNL and LANL HTGR safety research programs reviews.

\subsection{IAEA Specialists Meeting on Gas-Cooled Reactor Safety and Accident Analysis, Oak Ridge, Tennessee, May $13-15,1985$}

$$
\text { S. J. Ball J. C. Cleveland }
$$
R. M. Harrington

Program personnel attended the sessions and presented two programsponsored papers: "Simulation of Thermal Response of the 250 MWT Modular HTGR During Hypothetical Uncontrolled Heatup Accidents" (see Sect. 1.I) and "ORNL's NRC-Sponsored HTGR Safety and Licensing Analysis Activities for Fort St. Vrain and Advanced Reactors."

\subsection{DOE/NRC Meeting on Licensing Plans for the Advanced HTGR P1ant Design, Bethesda, Maryland, May 31, 1985}

R. M. Harrington

DOE and their contractors presented a proposed licensing plan and approach to developing an HTGR licensing bases for initial NRC review and comment. 


\section{REFERENCE}

1. S. J. Ball, ORECA-I: A Digital Computer Code for Simulating the Dynamics of HTGR Cores for Emergency Cooling Analyses, ORNL/TM5159, Union Carbide Corp. Nuclear Div., Oak Ridge Nat1. Lab., April 1976. 
NUREG/CR-4402

Volume 2

ORNL/TM-9798/V2

Dist. Category R8

\section{Internal Distribution}

$\begin{aligned} \text { 1-5. } & \text { S. J. Ball } \\ \text { 6. } & \text { N. E. Clapp } \\ \text { 7-11. } & \text { J. C. Cleveland } \\ \text { 12. } & \text { J. C. ConkIin } \\ \text { 3-14. } & \text { J. A. Getsi } \\ \text { 5-19. } & \text { R. M. Harrington } \\ \text { 20. } & \text { J. E. Jones, Jr. } \\ 21 . & \text { P. R. Kasten } \\ 22 . & \text { A. D. Kelmers } \\ 23 . & \text { T. S. Kress } \\ \text { 24. } & \text { T. B. Lindemer } \\ 25 . & \text { A. P. Malinauskas }\end{aligned}$

26. D. L. Moses

27. J. P. Sanders

28. R. S. Stone

29. H. E. Tramme11

30. R. P. Wichner

31-35. J. H. Wilson

36. I\&C Publications office

37. ORNL Patent Office

38. Central Research Library

39. Document Reference Section

40-41. Laboratory Records Department

42. Laboratory Records, RC

\section{External Distribution}

43-46. Director, Office of Nuclear Regulatory Research, Nuclear Regulatory Commission, Washington, DC 20555

47. Chief, Advanced Safety Technology Branch, Division of Accident Evaluation, Office of Nuclear Regulatory Research, Nuclear Regulatory Commission, Washington, DC 20555

48. Office of Assistant Manager for Energy Research and Development, DOE, ORO, Oak Ridge, TN 37831

49-50. Technical Information Center, DOE, Oak Ridge, TN 37831

51-250. Given distribution as shown in category R8 (10-NTIS) 


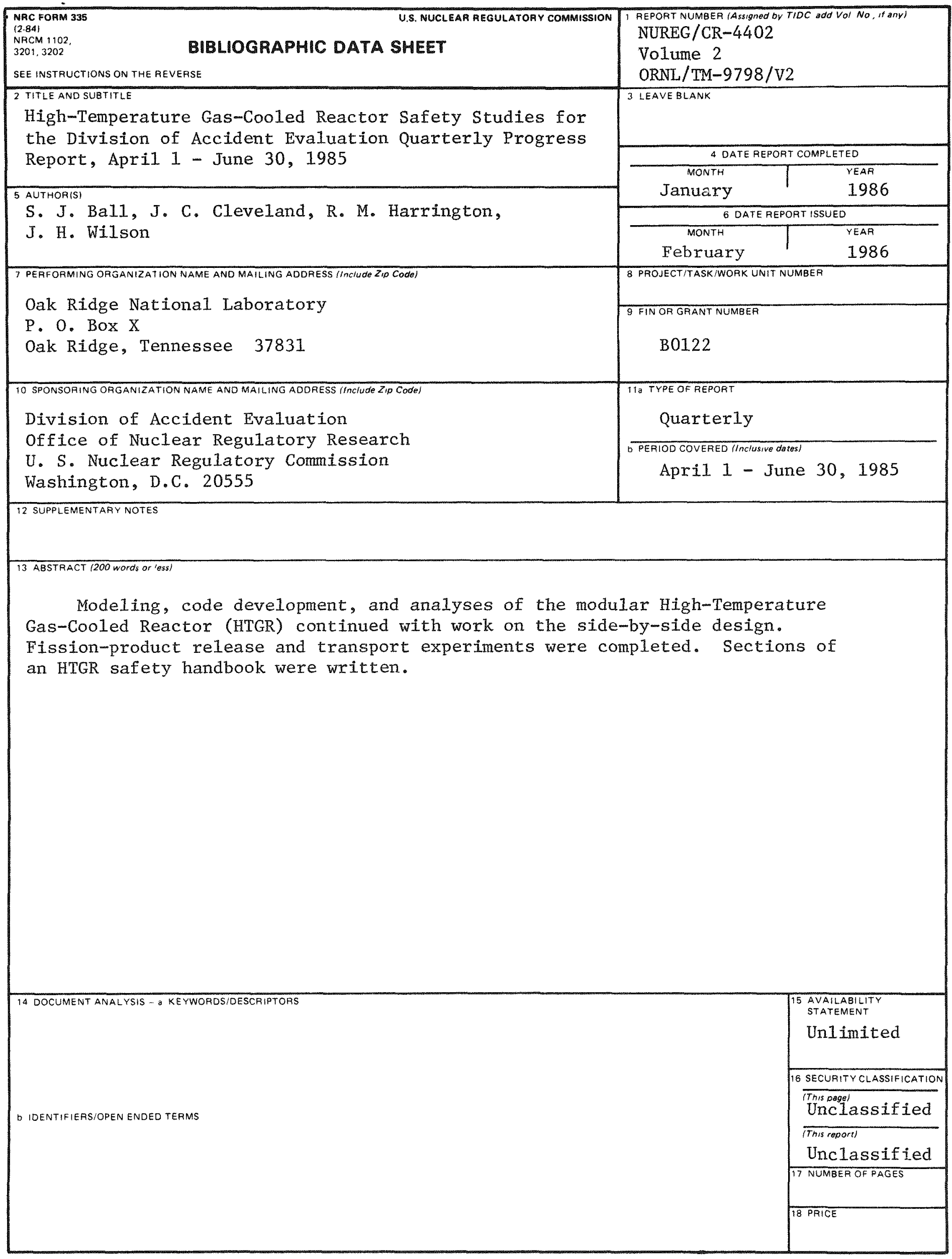

